\title{
Clinical Immunosuppressants Inhibit Inflammatory, Proliferative, and Reprogramming Potential, But Not Angiogenesis of Human Pancreatic Duct Cells
}

\author{
Lei Ding, ${ }^{* 1}$ Yves Heremans, $\dagger^{1}$ Daniel Pipeleers, $\$$ Zhidong Ling, $\$$ \\ Harry Heimberg, $\dagger$ Conny Gysemans, ${ }^{* 2}$ and Chantal Mathieu*2 \\ *Laboratory of Clinical and Experimental Endocrinology, Campus Gasthuisberg O\&N1, \\ Faculty of Medicine, Katholieke Universiteit Leuven (KU Leuven), Leuven, Belgium \\ $\dagger$ Laboratory of Beta Cell Neogenesis (BENE), Diabetes Research Center, Faculty of Medicine and Pharmacy, \\ Vrije Universiteit Brussel (VUB), Brussels, Belgium \\ †Laboratory of Diabetes Pathology and Therapy, Diabetes Research Center, Faculty of Medicine and Pharmacy, \\ Vrije Universiteit Brussel (VUB), Brussels, Belgium
}

\begin{abstract}
The presence of pancreatic duct cells in clinical islet grafts may affect long-term metabolic success. Human pancreatic duct cells express factors that may exert both protective and damaging effects on islet cells in the graft. Here we studied the potential of commonly used immunosuppressive drugs in islet transplantationsirolimus, tacrolimus, and mycophenolate mofetil (MMF) - to influence the inflammatory and angiogenic capacity of human pancreatic duct cells in addition to their proliferation and reprogramming abilities. Our data show that the expression of specific proinflammatory cytokines by the human pancreatic duct cells was either unaltered or inhibited by the immunosuppressants studied, especially tacrolimus and MMF, whereas expression of chemotactic and angiogenic factors was unaffected. Although none of the immunosuppressants directly led to duct cell death, MMF prevented duct cell proliferation, and sirolimus inhibited neurogenin 3-mediated duct-to-(neuro)endocrine cell reprogramming. Our data indicate that the immunosuppressant tacrolimus was the least aggressive on the angiogenic, proliferative, and reprogramming potential of human pancreatic duct cells, while it was most powerful in inhibiting inflammatory cytokines, which may influence the outcome of islet transplantation.
\end{abstract}

Key words: Human pancreatic duct cell; Islet transplantation; Immunosuppressant; Cytokines; Angiogenesis; Dedifferentiation

\section{INTRODUCTION}

The presence of pancreatic duct cells in most islet grafts prepared for clinical use may be of interest to the potential of $\beta$-cell renewal in both islet implants and islet engraftment. These cells classically compose almost half of the cells in islet preparations $(25,43)$ and have been attributed $\beta$-cell differentiating capacities in addition to the ability to secrete angiogenic factors, possibly promoting islet engraftment $(32,47,48)$. These cells also secrete proinflammatory cytokines (36), which may be detrimental to graft function and survival. Conflicting data have been published on the role of pancreatic duct cells in islet preparations for clinical use. In one study, the number of duct "contaminants" transplanted correlated with a better outcome in human islet recipients (43), but this has so far not been confirmed. In preclinical models testing human $\beta$-cell implants, a negative correlation was observed (20), which was consistent with earlier work on rat $\beta$-cell implants $(22,24,38)$. On the other hand, cotransplantation with duct cells significantly shortened the time lag before proper function of implanted islets, apparently due to better vascular endothelial growth factor (VEGF)-dependent islet graft engraftment (47). This suggests that transplanted human islets may be better vascularized when duct cells are present in the islet preparations.

Islet survival in type 1 diabetic (T1D) patients is also determined by the immune attack of the recipient that is not only composed of allograft rejection but also of

Received November 28, 2013; final acceptance July 9, 2014. Online prepub date: July 14, 2014.

${ }^{1}$ These authors provided equal contribution to this work.

${ }^{2}$ Share senior authorship.

Address correspondence to Chantal Mathieu, M.D., Ph.D., Campus Gasthuisberg O\&N1, Laboratory of Clinical and Experimental Endocrinology,

Herestraat 49 bus 902, B-3000 Leuven, Belgium. Tel: +32-16-346023; Fax: +32-16-330718; E-mail: chantal.mathieu@uzleuven.be 
autoimmunity (18). This process can only be arrested through a combination of antibody-based induction regimens and chronic use of immunosuppressants. Although steroid-free immunosuppressive regimens have greatly improved the long-term success of human islet transplantation $(41,42)$, the adverse effects of modern immunosuppressive drugs have been extensively discussed (46). Many of the drugs commonly used, including rapamycin (sirolimus), FK506 (tacrolimus), and mycophenolate mofetil (MMF), negatively affect function and viability of mature $\beta$-cells (21). In particular, the calcineurin inhibitor tacrolimus causes serious islet cell damage and abnormal glucose metabolism in rodent models (29) and in diabetic patients receiving a pancreas allograft (30). Moreover, both sirolimus and tacrolimus prevent $\beta$-cell regeneration after injury (34), and MMF inhibits in vitro $\beta$-cell neogenesis (12). Furthermore, besides the direct toxic effects on $\beta$-cells, drug-related inhibitory effects on the process of islet angiogenesis have been documented (8).

In the present study, we set out to investigate the effects of the immunosuppressive drugs sirolimus, tacrolimus, and MMF on human pancreatic duct cells with regard to their inflammatory, angiogenic, proliferative, and reprogramming potential.

\section{MATERIALS AND METHODS}

\section{Immunosuppressive Drugs}

The immunosuppressive drugs and their concentrations were selected based on current and standard use in clinical islet transplantation. The drugs included sirolimus [Rapamune ${ }^{\mathrm{TM}}$; Pfizer (formerly by Wyeth), Sandwich, Kent, UK] at concentration of $25 \mathrm{ng} / \mathrm{ml}$, tacrolimus (Prograf ${ }^{\mathrm{TM}}$; Astellas Pharma, Kastrup, Denmark) at concentration of $25 \mathrm{ng} / \mathrm{ml}$, and MMF (CellCept ${ }^{\mathrm{TM}}$; Hoffmann-La Roche; Basel, Switzerland) at concentration of $17.5 \mu \mathrm{g} / \mathrm{ml}$. Drug dilutions were made from fresh stock before each experiment. Sirolimus, tacrolimus, and MMF were solubilized in dimethyl sulfoxide (DMSO; Sigma-Aldrich, St. Louis, MO). Control cultures were cultured in the absence of immunosuppressive drugs under otherwise identical conditions as treated cells (presence of DMSO vehicle).

\section{Duct Cell Preparation and Culture}

Human pancreatic duct cells were obtained from heartbeating cadaveric nondiabetic donors. Human donor pancreases were procured at European hospitals and made available to the Beta Cell Bank in Brussels through the intermediate of the Eurotransplant Foundation (Leiden, The Netherlands). Preparations (16 donors, without diabetes; 9 males and 7 females; range of donor ages was between 8 and 64 years) that could not be used for transplantation were made available for related research according to the guidelines of Eurotransplant and were used across all studies. The nonendocrine fraction was cultured in HAM's F10 (Invitrogen/Life Technologies, Ghent, Belgium), $0.5 \%$ bovine serum albumin (BSA; Sigma-Aldrich), $7.5 \mathrm{mM}$ glucose (Merck, Darmstadt, Germany), $100 \mathrm{U} / \mathrm{ml}$ penicillin (Continental Pharma, Brussels, Belgium), $100 \mu \mathrm{g} / \mathrm{ml}$ streptomycin (SigmaAldrich), and $1 \mathrm{mM} \mathrm{L-glutamine} \mathrm{(Sigma-Aldrich)} \mathrm{for}$ at least 4 days (32). Afterward, the nonendocrine fraction contained $>90 \%$ cytokeratin $(\mathrm{CK}) 19$-positive duct cells, $1-3 \%$ endocrine cells, and $<10 \%$ acinar cells, as determined previously (15). Depending on the experimental setup, the duct cells were maintained in serumfree medium (cultures in suspension) or cultured in the presence of $5 \%$ fetal bovine serum (Invitrogen/Life Technologies) on tissue culture-treated plastic to allow attachment and monolayer formation. All procedures were approved by the Institutional Ethical Committees of the University Hospitals of Leuven (permission ML3201) and Brussels (permission 2010/193).

\section{Duct Cell Transplantation}

Female nonobese diabetic-severe combined immunodeficient (NOD-scid) mice, aged 10-17 weeks, were used as duct cell transplant recipients (KU Leuven breeding colony, Leuven, Belgium). Twenty-four hours before transplantation, the immunosuppressive regimen was started. Mice were gavaged with sirolimus $(0.2 \mathrm{mg} / \mathrm{kg} /$ day), tacrolimus (0.2 mg/kg/day), or MMF (100 mg/ $\mathrm{kg} /$ day) (0-24 h), followed by $40 \mathrm{mg} / \mathrm{kg} /$ day (2-14 days). Control mice were treated with vehicle. Mice were anesthetized by intraperitoneal injection of avertin (2, 2, 2-tribromoethanol, $500 \mathrm{mg} / \mathrm{kg}$ body weight; SigmaAldrich). The left kidney was exposed through a lumbar incision, and recipient mice were grafted with $5 \times 10^{6}$ human pancreatic duct cells under the kidney capsule via a sterile tubing system (PE50; BD Biosciences, Erembodegem, Belgium). At indicated time points, serum samples were collected, and graft-bearing kidneys were removed for RNA isolation and stored at $-80^{\circ} \mathrm{C}$.

\section{ELISA}

Human interleukin (IL)-8 or VEGF were measured in sera of duct cell-transplanted NOD-scid mice using enzyme-linked immunosorbent assay (ELISA) kits from eBioscience Inc. (San Diego, CA).

\section{Duct Cell Angiogenesis}

Human pancreatic duct cells were tested in in vivo chorioallantoic membrane (CAM) angiogenesis assay. Briefly, fertilized white leghorn chicken eggs (Wyverkens, Halle, Belgium) were incubated at $37^{\circ} \mathrm{C}$ for 3 days prior to removing $3 \mathrm{ml}$ of albumen to detach the shell from the developing CAM. Next, a window was made in the eggshell to expose the CAM. At day 9, sterile absorbable gelatin sponges 
(1-2 $\mathrm{mm}^{3}$; Hospithera, Brussels, Belgium) were impregnated with $5 \times 10^{5}$ human adult pancreatic duct cells (kept in suspension for 6 days in the presence or absence of immunosuppressive drugs) and placed on the CAM. Sponges were also loaded with phosphate-buffered saline $/ 0.1 \%$ BSA $(1 \mathrm{mg} / \mathrm{ml}, \sim 50 \mu \mathrm{g} /$ embryo $)$ as negative control and with recombinant human VEGF-A ${ }_{165}(100 \mu \mathrm{g} / \mathrm{ml}$, $\sim 5 \mu \mathrm{g} / \mathrm{embryo}$; R\&D Systems, Abingdon, Oxon, UK) as positive control. At day 13, CAMs were fixed with $4 \%$ paraformaldehyde (PFA; Sigma-Aldrich), and the area around the implants was analyzed using a Zeiss Lumar V.12 stereomicroscope (Carl Zeiss, Jena, Germany).

\section{Duct Cell Proliferation and Death}

After monolayer formation and addition of clinically relevant concentrations of selected immunosuppressive drugs or control vehicles, proliferation was stimulated by the addition of human epidermal growth factor (EGF; 25 or $50 \mathrm{ng} / \mathrm{ml}$; R\&D Systems). After 3 days of additional culture, cells were fixed with 4\% PFA (Sigma-Aldrich) and stained for the duct cell marker CK19 (mouse antihuman CK19; 1:100; DakoCytomation, Glostrup, DK) and the proliferation marker Ki-67 (rabbit anti-human Ki-67; 1:500; Abcam, Cambridge, UK) as previously described (39). The preparations were analyzed on a Nikon Eclipse Ti inverted fluorescence microscope (Nikon Instruments Europe b.v., Kingston, Surrey, UK). For each duct cell preparation, 10 microscopic fields of each condition were examined to score sufficient cells.

The numbers of apoptotic duct cells were assessed by a previously reported assay making use of the DNA-

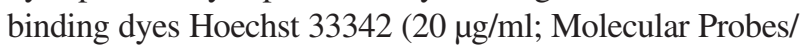
Invitrogen) and propidium iodide $(10 \mu \mathrm{g} / \mathrm{ml}$; Molecular Probes/Invitrogen) (10).

\section{Duct Cell Reprogramming}

Recombinant, replication-deficient adenoviruses expressing green fluorescent protein (AdGFP) and neurogenin 3 (Ngn3) in combination with GFP (AdNgn3-GFP) were generated following standard procedures as previously described (14). Briefly, adenoviral plasmid pAdEasy1 and shuttle vector pAdTrack-CMV were donated by Dr. He and Dr. Vogelstein (Johns Hopkins Oncology Center, Baltimore, MD, USA). The coding sequence of hemagglutinin-tagged mouse Ngn3 was subcloned in the shuttle vector and constitutively expressed under control of the cytomegalovirus (CMV) promotor. pAdTrack-CMV contained the enhanced-GFP cDNA downstream of a separate CMV promotor. After monolayer formation, human pancreatic duct cell cultures were transduced during 4 $\mathrm{h}$ at a multiplicity of infection of 50 with AdNgn3-GFP or AdGFP as previously described (16). After infection, pancreatic duct cells were washed twice and cultured in the absence or presence of immunosuppressive drugs for an additional 6 days. Thereafter, cells were either lysed for RNA extraction to perform reverse-transcription quantitative PCR (RT-qPCR) or were fixed with $4 \%$ PFA (Sigma-Aldrich) and subsequently stained for the (neuro)endocrine cell marker synaptophysin (rabbit antisynaptophysin; 1:50; Invitrogen) and the $\beta$-cell marker insulin (guinea pig anti-insulin 1:100; Invitrogen) as previously described (17). Nuclei were counterstained with 4',6-diamidino-2-phenylindole (DAPI). The preparations were analyzed on a Nikon Eclipse Ti inverted fluorescence microscope (Nikon Instruments Europe b.v.). For each duct cell preparation, 5-10 microscopic fields of each condition were examined.

\section{RNA Isolation and cDNA Synthesis}

Total RNA was isolated using the high pure RNA isolation kit (Roche Diagnostics, Vilvoorde, Belgium) or the SV Total RNA isolation kit (Promega, Madison, WI, USA). RNA purity was checked by using a NanoDrop ${ }^{\circledR}$ spectrophotometer (Thermo Scientific, Waltham, MA, USA). The A260/A230 ratios were typically above 1.7, while A260/A280 ratios were between 2.0 and 2.2, indicative for the high purity of RNA samples. Moreover, the integrity of the RNA was checked by the use of the 2100 Bioanalyzer (Agilent, Santa Clara, CA, USA), and samples with RNA integrity numbers (RIN) above 7.5 were considered appropriate. A fixed amount of RNA $(1 \mu \mathrm{g})$ was reverse transcribed into cDNA (Superscript II kit; Invitrogen/Life Technologies) as previously described (35). cDNA was stored frozen at $-80^{\circ} \mathrm{C}$ until use.

\section{$R T-q P C R$}

Kinetic PCR was performed on a StepOnePlus ${ }^{\mathrm{TM}}$ system (Applied Biosystems/Life Technologies, Carlsbad, CA, USA) with gene-specific primers using either Fast SYBR $^{\circledR}$ Green Master Mix or a gene-specific TaqMan ${ }^{\circledR}$ probe in combination with TaqMan $^{\circledR}$ Fast Universal Master Mix (Life Technologies, Carlsbad, CA, USA) as described previously (35). The primers, probes, and reaction conditions for human IL-6, IL-8, tumor necrosis factor (TNF)- $\alpha$, synaptophysin, insulin, neurogenic differentiation 1 (NeuroD1), paired box gene 4 (Pax4), and insulinoma-associated 1 (Insm1) were as published $(13,32,35,44)$, except for human IL-1 $\beta$, VEGF (total), the $\mathrm{C}-\mathrm{X}-\mathrm{C}$ motif chemokines, and the ribosomal protein $\mathrm{L} 27$ (RPL27) (see Table 1). All qPCR assays were validated for optimal range of primer annealing temperatures, reaction efficiency, and specificity using a standard set of samples. All experiments were designed with a combination of biological and technical replicates (triplicate), and samples were normalized to RPL27 reference gene (not regulated by immunosuppressants). Relative expression was calculated using the Pfaffl method with real-time PCR efficiency correction (37). 
Table 1. Primer and Probe Characteristics

\begin{tabular}{|c|c|c|c|}
\hline Target & Sequence & PCR Efficiency & $\begin{array}{c}\mathrm{Cq} \\
\text { Range }\end{array}$ \\
\hline $\mathrm{IL}-1 \beta$ & $\begin{array}{l}\text { F 5'-TACCTGAGCTCGCCAGTGAA-3' } \\
\text { R 5'-CAGAGGTCCAGGTCCTGGAA-3' } \\
\text { SYBR }\end{array}$ & 105 & $25-32$ \\
\hline CXCL1 & $\begin{array}{l}\text { F 5'-TCTGAGGAGCCTGCAACATG-3' } \\
\text { R 5'-CATTGGCCATTTGCTTGGA-3' } \\
\text { P 5'-AGCCACTGTGATAGAGGCTGGCGG-3' }\end{array}$ & 92 & $21-32$ \\
\hline CXCL4 & $\begin{array}{l}\text { F 5'-TGCTGCTCCTGCCACTTGT-3' } \\
\text { R 5'-ACCTCCAGGCTGGTGATGTG-3' } \\
\text { P 5'-ACCTGCAGTGCCTGTGTGTGAAGACC-3' }\end{array}$ & 106 & $25-32$ \\
\hline CXCL5 & $\begin{array}{l}\text { F 5'-, ACGCAAGGAGTTCATCCCAA-3' } \\
\text { R 5'-TCCTTCCCGTTCTTCAGGG-3' } \\
\text { P 5'-ATGATCAGTAATCTGCAAGTGTTCGCCATAGG-3' }\end{array}$ & 104 & $26-32$ \\
\hline CXCL9 & $\begin{array}{l}\text { F 5'-GTTCTTTTCCTCTTGGGCATC-3' } \\
\text { R 5'-AGGAACAGCGACCCTTTCTCA-3' } \\
\text { P 5'-TGCTGGTTCTGATTGGAGTGCAAGGA-3' }\end{array}$ & 90 & $28-32$ \\
\hline CXCL10 & $\begin{array}{l}\text { F 5'-CAGAATCGAAGGCCATCAAGA-3' } \\
\text { R 5'-GCCTCTGTGTGGTCCATCCT-3' } \\
\text { P 5'-AAGGAAAGGTCTAAAAGATCTCCTTAAAACCAGAGGG-3' }\end{array}$ & 88 & $20-32$ \\
\hline CXCL11 & $\begin{array}{l}\text { F 5'-AGGACGCTGTCTTTGCATAGG-3' } \\
\text { R 5'-TTGGGATTTAGGCATCGTTGT-3' } \\
\text { P 5'-AAAGCAGTGAAAGTGGCAGATATTGAGAAAGCCT-3' }\end{array}$ & 99 & $26-32$ \\
\hline VEGF & $\begin{array}{l}\text { F 5'- CTTGCGCTTTCGTTTTTGC-3' } \\
\text { R 5'- ACCAAGGCCAGCACATAGGA-3' } \\
\text { P 5'- CAGCACAACAAATGTGAATGCAGACCAA-3' }\end{array}$ & 88 & $25-33$ \\
\hline RPL27 & $\begin{array}{l}\text { F 5'-TGTCGTCAATAAGGATGTCTTCAGA-3' } \\
\text { R 5'-TGCCTGTCTTGTATCTCTCTTCAAA -3' } \\
\text { SYBR }\end{array}$ & 100 & $17-27$ \\
\hline
\end{tabular}

F, forward; R, reverse; P, probe; SYBR, Fast SYBR ${ }^{\circledR}$ Green; Cq [quantification cycle, also referred to as Ct (threshold cycle)]; IL, interleukin; CXCL1, chemokine C-X-C motif ligand 1; VEGF, vascular endothelial growth factor; RPL27, ribosomal protein L27.

\section{Statistics}

Statistical analyses were performed with GraphPad Prism software (La Jolla, San Diego, CA, USA). Normality was checked using the D'Agostino-Pearson omnibus test. Non-Gaussian data were analyzed using a Kruskal-Wallis test followed by a Dunn's post hoc test. Normally distributed data were analyzed using one-way ANOVA followed by a Bonferroni's post hoc test. A value of $p<0.05$ was considered statistically significant, and values represent mean \pm SEM unless otherwise stated.

\section{RESULTS}

Effect of Immunosuppressants on Expression of Inflammatory Cytokines and Chemokines by Transplanted Pancreatic Duct Cells

We and others demonstrated that human pancreatic duct cells express and release proinflammatory cytokines like IL-1 $\beta$, IL-6, and TNF- $\alpha(19,33)$. To evaluate the effect of immunosuppressants, we measured cytokine gene expression by human duct cell grafts, retrieved at different time points after implantation in NOD-scid

\section{FACING PAGE}

Figure 1. Effect of immunosuppressants on inflammatory cytokine and C-X-C chemokine expression in vivo. Human pancreatic duct cells $\left(5 \times 10^{6}\right.$ cells) were implanted under the kidney capsule of nonobese diabetic severe combined immunodeficient (NODscid) mice treated with or without immunosuppressants [sirolimus, tacrolimus, or mycophenolate mofetil (MMF)] for up to 6 days. (A) Interleukin (IL)-1 $\beta$, IL-6, tumor necrosis factor (TNF)- $\alpha$, and (B) C-X-C motif chemokine mRNA expression was measured in implanted grafts by RT-qPCR and normalized to ribosomal protein L27 (RPL27). Data are displayed in floating bar plots (displaying min-max and median values). Statistical significance was determined by nonparametric Kruskal-Wallis test followed by the Dunn's multiple testing. Multiplicity-adjusted $p$ values were used as ${ }^{*} p<0.01$ compared to untreated at $0 \mathrm{~h}$; $p<0.05$ and \#\#p<0.01 for condition with immunosuppressants versus the untreated within each time point. 


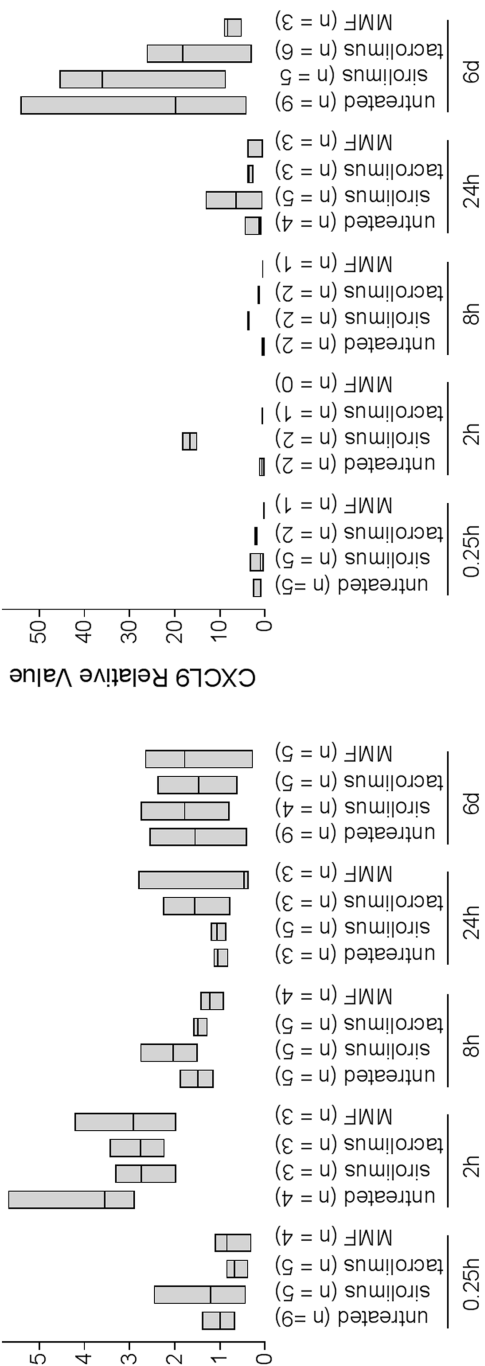

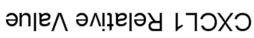

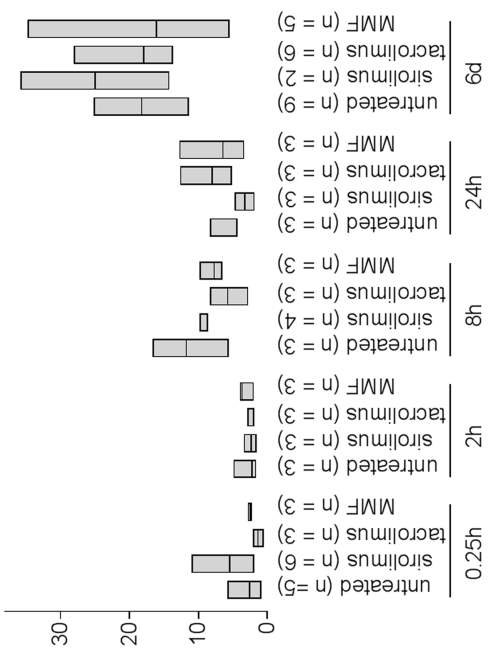

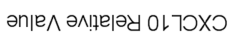

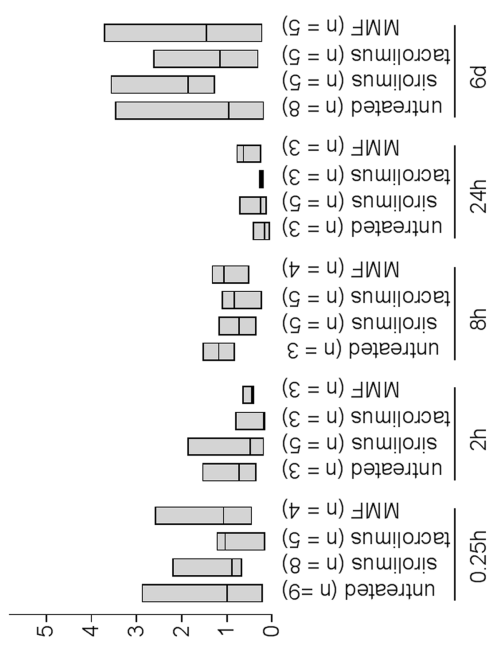

әп|еА әм!̣е|әу

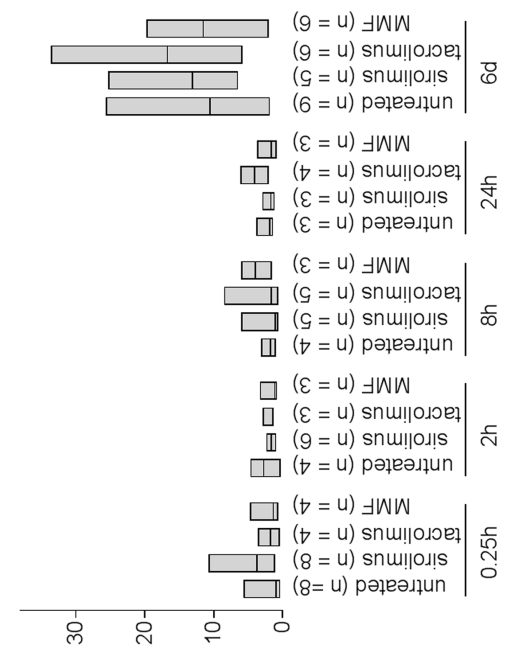

әп|е

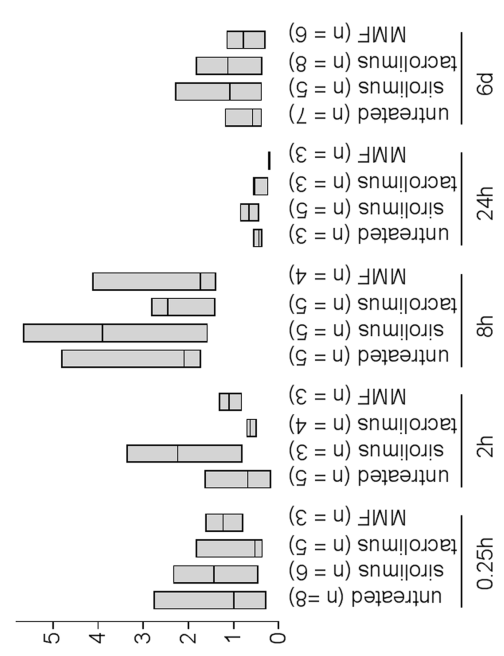

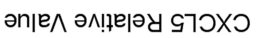
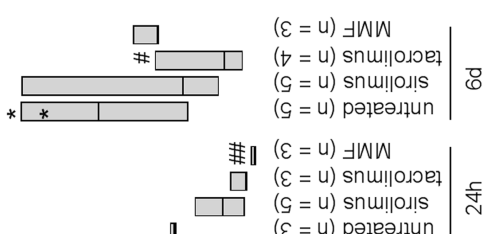

]

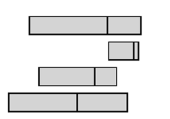

$(\varepsilon=u) \exists W W$

$(G=U)$ snu!l|0.joet $(\mathrm{g}=\mathrm{u})$ snu!l|d!l!s $(t=u)$ pәңеәдии

$(\varepsilon=u) \exists W W$
$(t=u)$ snull|0.गอ

$(t=u)$ snum!|odoet
$(g=u)$ snum!ou!s

$(\mathrm{t}=\mathrm{u})$ pəłеәдјun

$(\varepsilon=u) \exists$ JW

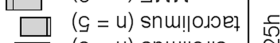

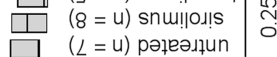

암다음

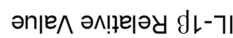

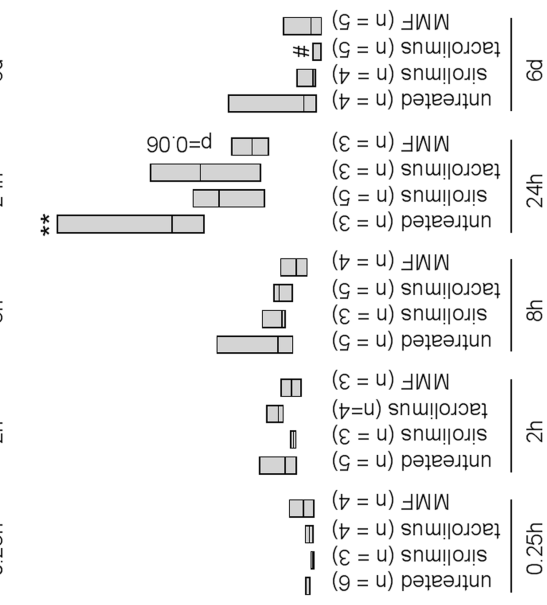

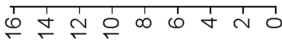

әп|е^ әм!̣е|әу 97

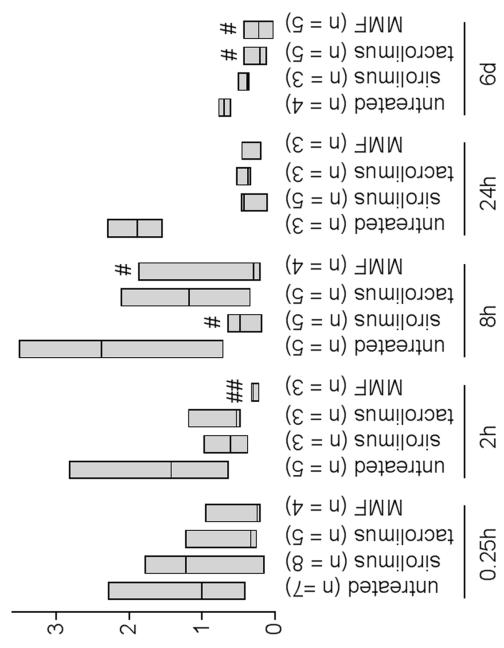

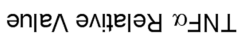


mice, treated or not with clinically relevant doses of immunosuppressants or their combination. Already at $2 \mathrm{~h}$ posttransplant, expression of the proinflammatory cytokines increased remarkably; IL-1 $\beta$, IL-6, and TNF- $\alpha$ were respectively 3.3-, 2.5-, and 1.4-fold higher compared to their basal control (Fig. 1A). IL-6 and TNF- $\alpha$ values reached their peak at 24 and $8 \mathrm{~h}$ posttransplant, respectively, but decreased to starting levels after 6 days of transplantation. On the other hand, IL-1 $\beta$ expression progressively increased to reach 6.7-fold higher levels at 6 days posttransplant (Fig. 1A).

Sirolimus substantially inhibited TNF- $\alpha$ expression at $8 \mathrm{~h}$ posttransplant $(77 \%$ reduction, $p<0.05$ vs. untreated control). Tacrolimus suppressed IL- $1 \beta$, IL-6, and TNF- $\alpha$ expression at $24 \mathrm{~h}(78 \%, 34 \%$, and $79 \%$ reduction vs. untreated controls, respectively) and more pronounced at 6 days $(70 \%$ reduction, $p<0.05,92 \%$ reduction, $p<0.05$, and $66 \%$ reduction, $p<0.05$ vs. untreated controls, respectively) after transplantation. Finally, MMF inhibited TNF- $\alpha$ expression at most time points studied, in addition to IL- $1 \beta$ and IL- 6 at $24 \mathrm{~h}$ posttransplant (90\% reduction, $p<0.01$ and $60 \%$ reduction, $p=0.06$ vs. untreated controls, respectively) (Fig. 1A).

Besides proinflammatory cytokines, we also examined the gene expression of a family of chemotactic/ angiogenic cytokines. After implantation in NOD-scid mice, CXCL1 expression in pancreatic duct cells peaked early (fourfold increase at $2 \mathrm{~h}$ ) and quickly returned to basal levels. CXCL4 and 5 in the human duct cell grafts increased at 6 days and $8 \mathrm{~h}$ after transplantation, respectively. Interestingly, expression of all CXCR3 ligands (CXCL9, 10, 11) had a relatively slow increase in the human duct cell implants and only reached their highest expression levels after 6 days posttransplantation (Fig. 1B). No significant effect of the immunosuppressants studied on the $\mathrm{C}-\mathrm{X}-\mathrm{C}$ chemokine expression by the transplanted duct cells could be observed.

\section{Effect of Immunosuppressants on Expression and Release of Pancreatic Duct Cell Angiogenic Factors In Vivo}

Human pancreatic duct cells are a source of angiogenic proteins $(19,32)$. We confirmed that mRNA expression of VEGF and in particular of IL-8 increased during the first day after implantation of human pancreatic duct cells under the kidney capsule of NOD-scid mice (Fig. 2A).
VEGF levels were 33\% higher after $2 \mathrm{~h}$ but decreased afterward; IL-8 expression peaked at $2 \mathrm{~h}$ and remained elevated until 6 days posttransplant (Fig. 2A). Overall, the immunosuppressants studied did not significantly affect the expression of VEGF or IL-8, though sirolimus increased the peak expression of IL- 8 at $2 \mathrm{~h}$ by an almost significant amount ( $p=0.06)$ (Fig. 2A).

Serum of the duct cell-implanted recipients was assayed for VEGF and IL-8 content, reflecting a similar pattern of IL-8 and VEGF as was seen locally in the graft, with comparable effects of the immunosuppressants (Fig. 2B).

To further test the effect of the selected immunosuppressive agents on the angiogenic potential of the human pancreatic duct cells, we used the CAM angiogenesis model. Inoculation of $5 \mu \mathrm{g}$ recombinant human VEGF markedly increased the number of blood vessels directed toward the implant (Fig. 3). On day 13, their number was almost fourfold higher than control implants containing $50 \mu \mathrm{g}$ BSA. A 2.5-fold increase was induced with sponges containing $5 \times 10^{5}$ human pancreatic duct cells without immunosuppressive treatment (Fig. 3). Pretreatment of human pancreatic duct cells with the selected immunosuppressive agents or their combination did not affect neovessel formation on the CAM when compared to the vehicle control (Fig. 3).

\section{Effects of Immunosuppressants on Pancreatic Duct Cell Proliferation and Death}

Under basal circumstances, the percentage of proliferating duct cells was low $(1.27 \pm 0.23 \%$ CK $19+\mathrm{Ki}-67+$ cells). Basal human duct cell proliferation was markedly decreased by sirolimus, MMF, and the combination treatment $(0.13 \pm 0.04 \%, 0.18 \pm 0.14 \%, p=0.05$, and $0.31 \pm 0.20 \%$ CK19+Ki-67+cells, respectively), whereas tacrolimus had no effect (Fig. 4A).

As described previously, EGF induced a dose-dependent increase in human pancreatic duct cell proliferation $(2.40 \pm 0.13 \%$ and $4.04 \pm 0.97 \%$ CK19 + Ki-67 + cells for the low- and high-dose EGF, respectively) (39) (Fig. 4A). MMF inhibited both low- and high-dose EGF-induced duct cell proliferation $(0.38 \pm 0.13 \%$ and $0.18 \pm 0.06 \%$ CK19+Ki-67+cells for MMF), while sirolimus and tacrolimus exerted no significant effect (Fig. 4A). The combination of the immunosuppressants also inhibited EGF-induced human pancreatic duct cell proliferation

\section{FACING FIGURE}

Figure 2. Effect of immunosuppressants on IL-8 and vascular endothelial growth factor (VEGF) expression in vivo. Human pancreatic duct cells $\left(5 \times 10^{6}\right.$ cells) were implanted under the kidney capsule of NOD-scid mice treated with or without immunosuppressants for up to 6 days. (A) Total IL-8 and VEGF mRNA expression by grafted duct cells was measured by RT-qPCR and normalized to RPL27. (B) IL-8 and VEGF content of serum was measured with ELISA. Data are displayed in floating bar plots (displaying min-max and median values). Statistical significance was determined by nonparametric Kruskal-Wallis test with post hoc Dunn's multiple testing. Multiplicity-adjusted $p$ values were used as $* p<0.05, * * p<0.01$ compared to untreated at $0 \mathrm{~h}$. 

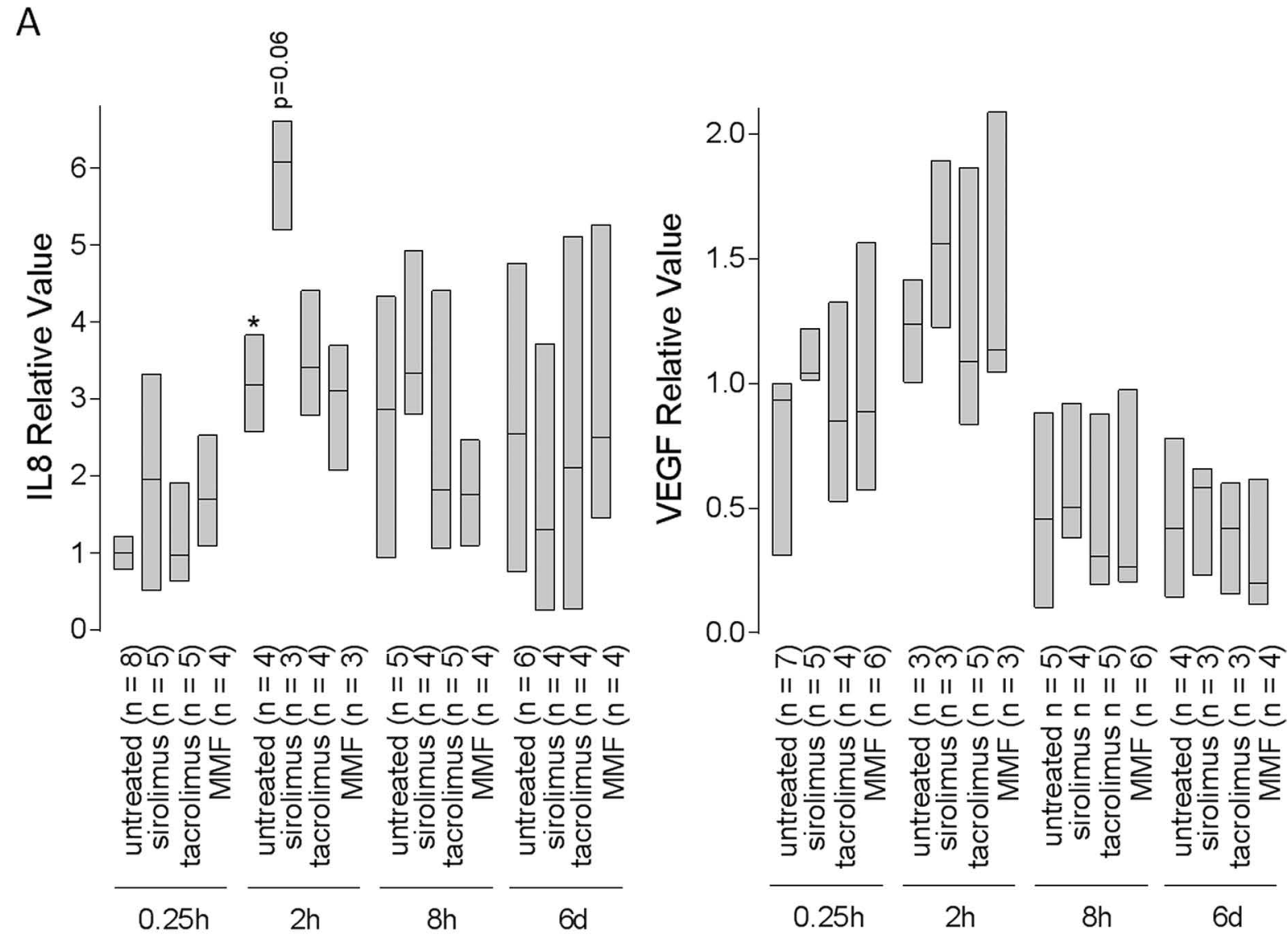

B
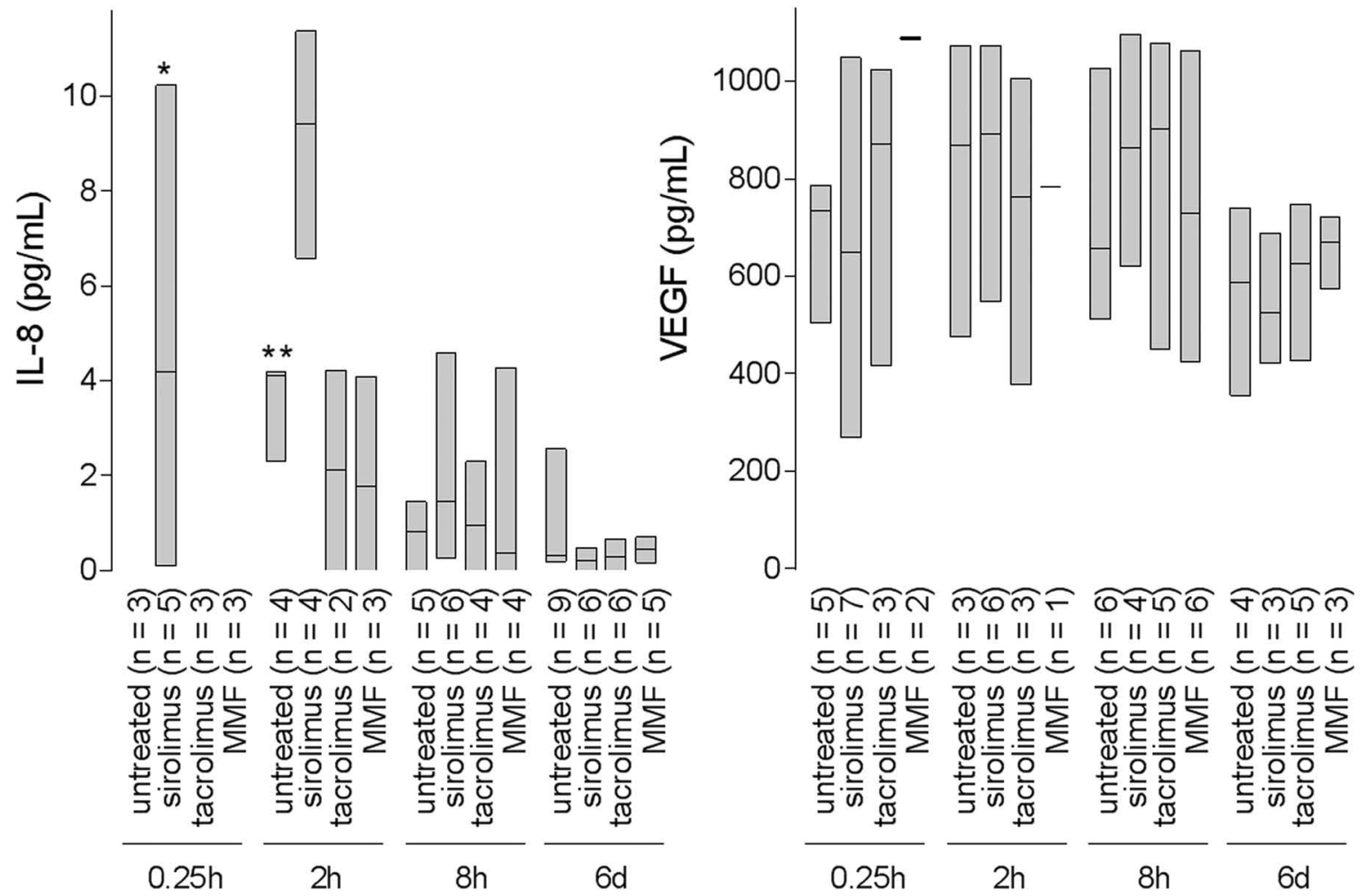

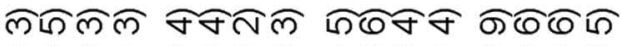
II II II II II II II II II II II II II II II II

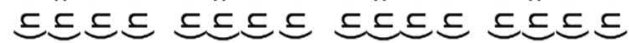

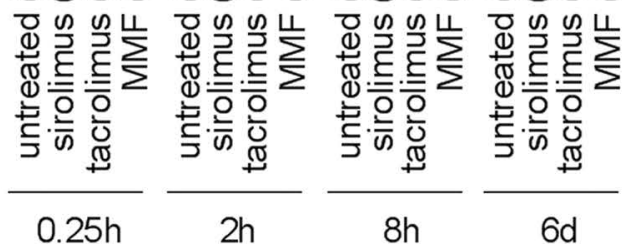

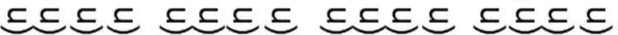

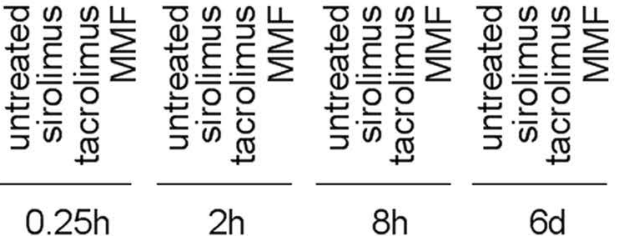



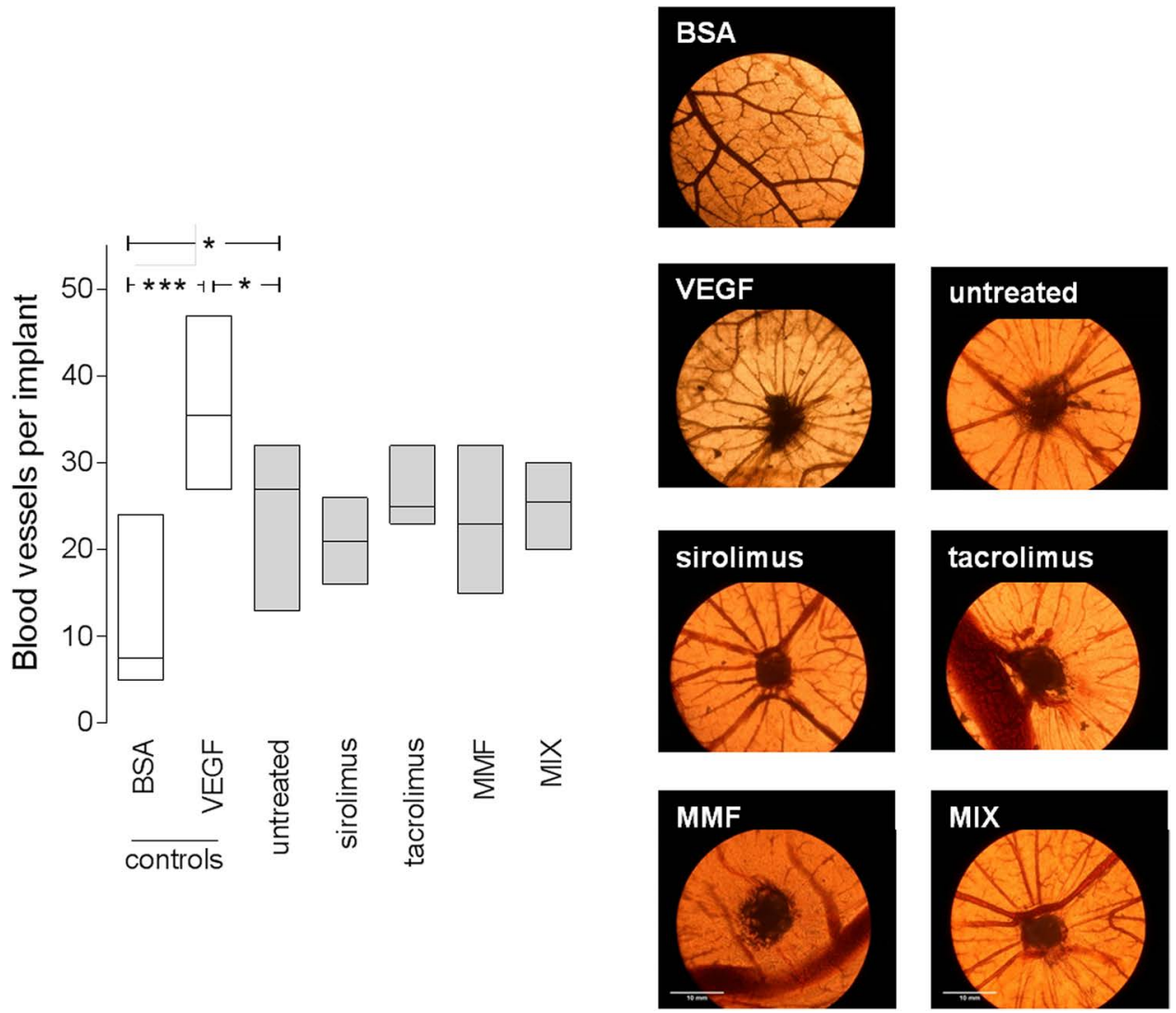

Figure 3. Effect of immunosuppressants on angiogenesis in chorioallantoic membrane (CAM) assay. Implants on the chick CAM with duct cells $\left(5 \times 10^{5}\right.$ cells) precultured with or without immunosuppressants. Number of vessels derived from implant is displayed in floating bar plots (displaying min-max and median values) of the average of 5 to 11 implants per condition (in total more than three independent experiments, using cells from different donors). Scale bar: $10 \mathrm{~mm}$. Statistical significance was determined by nonparametric Kruskal-Wallis test with post hoc Dunn's multiple testing. Multiplicity-adjusted $p$ values were used as $* p<0.05, * * * p<0.001$. BSA, bovine serum albumin; MIX, sirolimus, tacrolimus, and MMF.

$(0.34 \pm 0.23 \%$ and $0.50 \pm 0.31 \%$ CK19+Ki- $67+$ cells for low- and high-dose EGF, respectively). No clear effects on duct cell apoptosis were observed under any condition (Fig. 4B).

\section{Effects of Immunosuppressants on Ngn3-Mediated Pancreatic Duct Cell Reprogramming}

As shown in Figure 5A, similar to our published data $(17,44)$, nontransduced or AdGFP-transduced duct cells express little or no NeuroD1, Pax4, Insm1, insulin, and synaptophysin. Adenoviral transduction of duct cells under basal conditions with Ngn3-GFP induces a substantial increase in synaptophysin and a minor increase in insulin mRNA expression (Fig. 5A). Moreover, the expression of NeuroD1, Pax4, and Insm1 increased significantly in human adult pancreatic duct cells transduced with Ngn3-GFP (Fig. 5A). At the protein level, nontransduced or AdGFP-transduced duct cells display little or no (neuro)endocrine characteristics, while 6 days after AdNgn3-GFP transduction the fraction of cells that

\section{FACING PAGE}

Figure 4. Effects of immunosuppressants on duct cell proliferation. Human pancreatic duct cells were supplemented with or without epidermal growth factor (EGF) (25 or $50 \mathrm{ng} / \mathrm{ml}$ ) and cultured with or without immunosuppressants. (A) After 3 days of exposure to different drugs, CK19 (red)/Ki-67 (green) staining (right panels) was performed to calculate duct cell proliferation as described in the Materials and Methods. Percentage of CK19+Ki- $67^{+}$cells is shown in the left panel. Data are displayed in floating bar plots with minmax and median values of three to five independent experiments, using cells from different donors. Scale bar: $100 \mu \mathrm{m}$. (B) Percentage of apoptotic duct cells is displayed in floating bars with min-max and median values of more than three independent experiments, using cells from different donors. Scale bar: $100 \mu \mathrm{m}$. Statistical significance was determined by nonparametric Kruskal-Wallis test followed by the Dunn's multiple testing. Multiplicity-adjusted $p$ values were used as $* p<0.05$ compared to untreated without EGF; $\# p<0.05, \# \# p<0.01$ compared to untreated within different EGF dosage. 

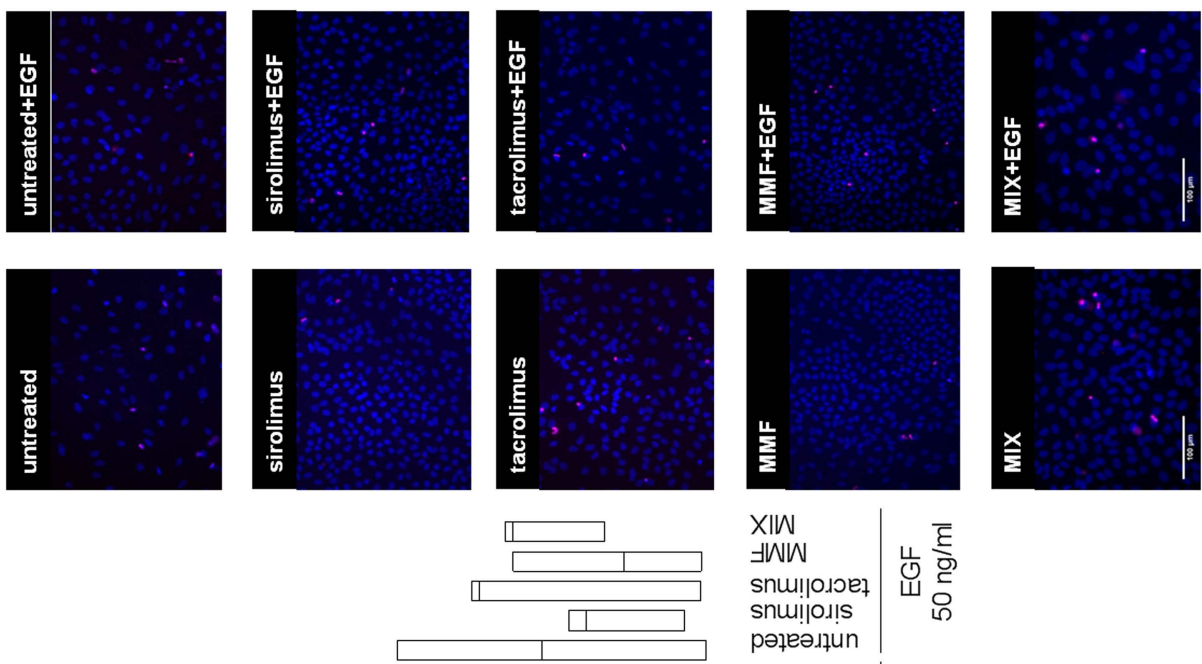

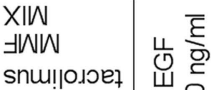

snui!|0l!s

рәтеәдұи

XIN

$\exists W W$

snu!|oıอe

snu!!|0ג!s

рәтеәлии

XIW

$\exists W W$

snu!|0.10e]

snu!|0ג!s

рәтеәлии

| $\frac{\text { ह }}{\text { पू }}$

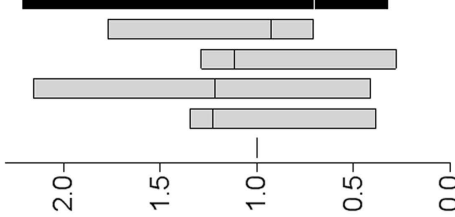

.

(\%) s!̣sołdode ॥əว ן๐n

$\infty$
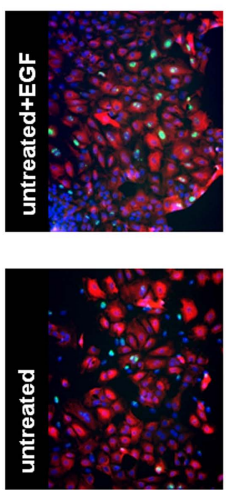
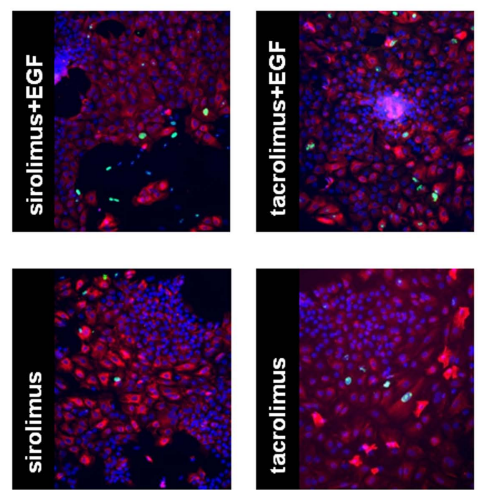
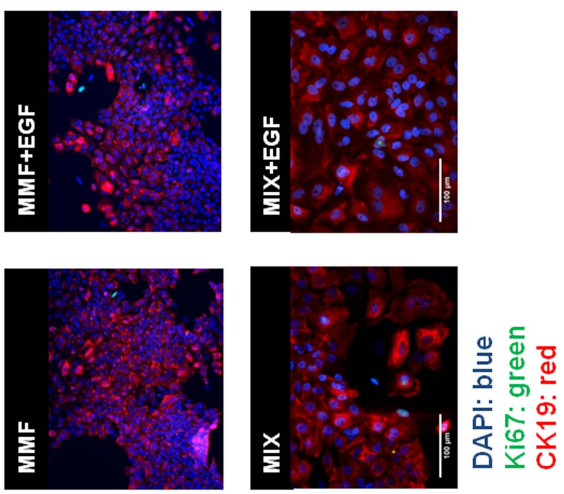
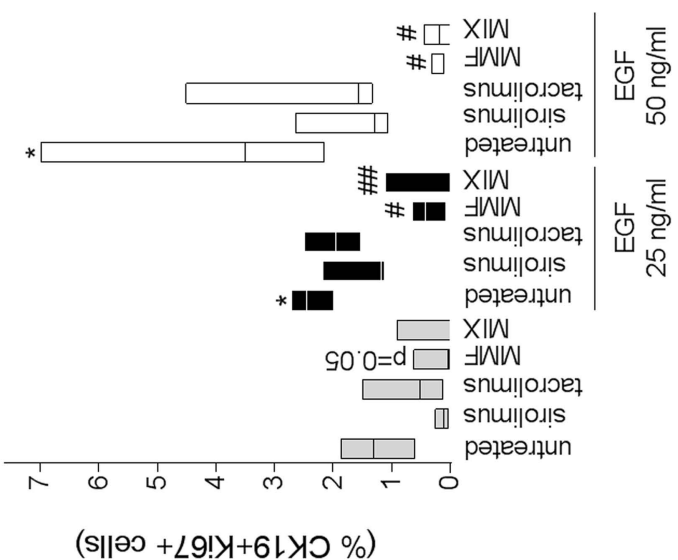

$\varangle$

(s॥ə0 + L9!પ્ર+6L

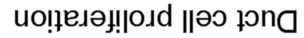

рәтеәлии 


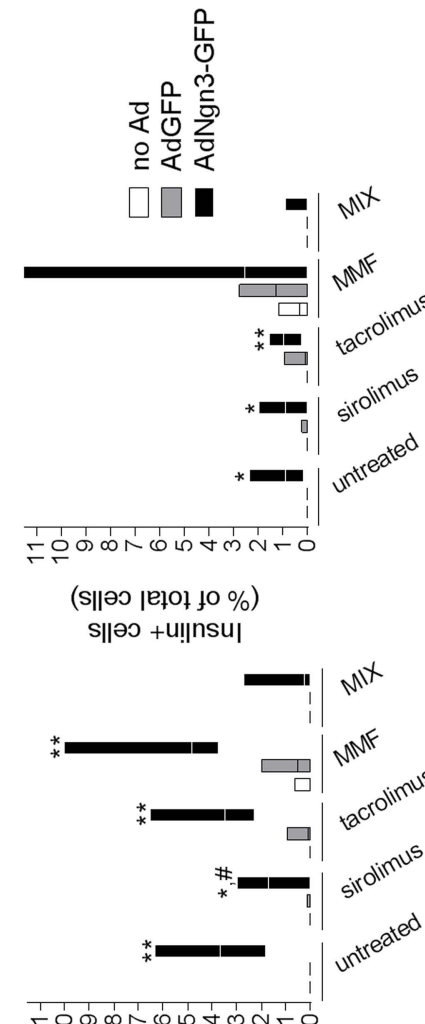

등 ๓

(s|ㅣ ןеоㅏ fo \%) s|ləo +u!sরydoldeu $\mathrm{s}$
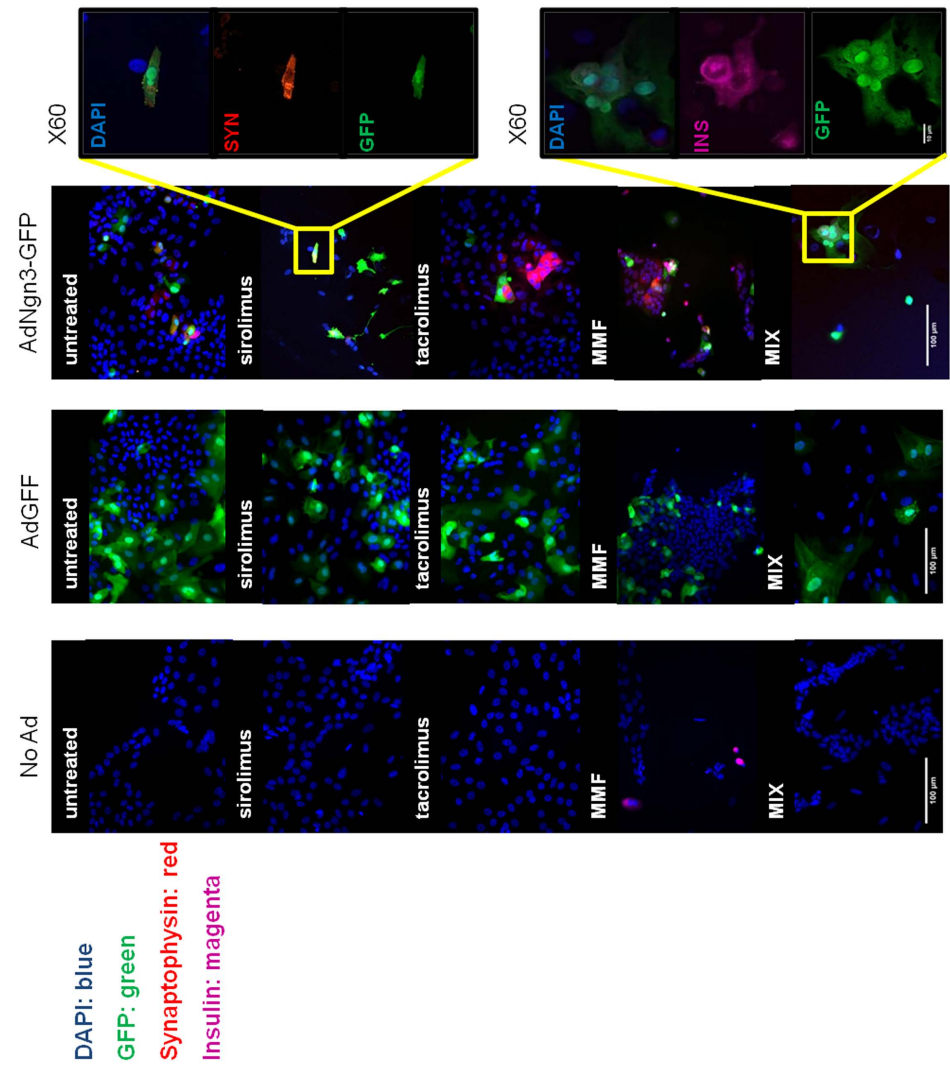

$\infty$
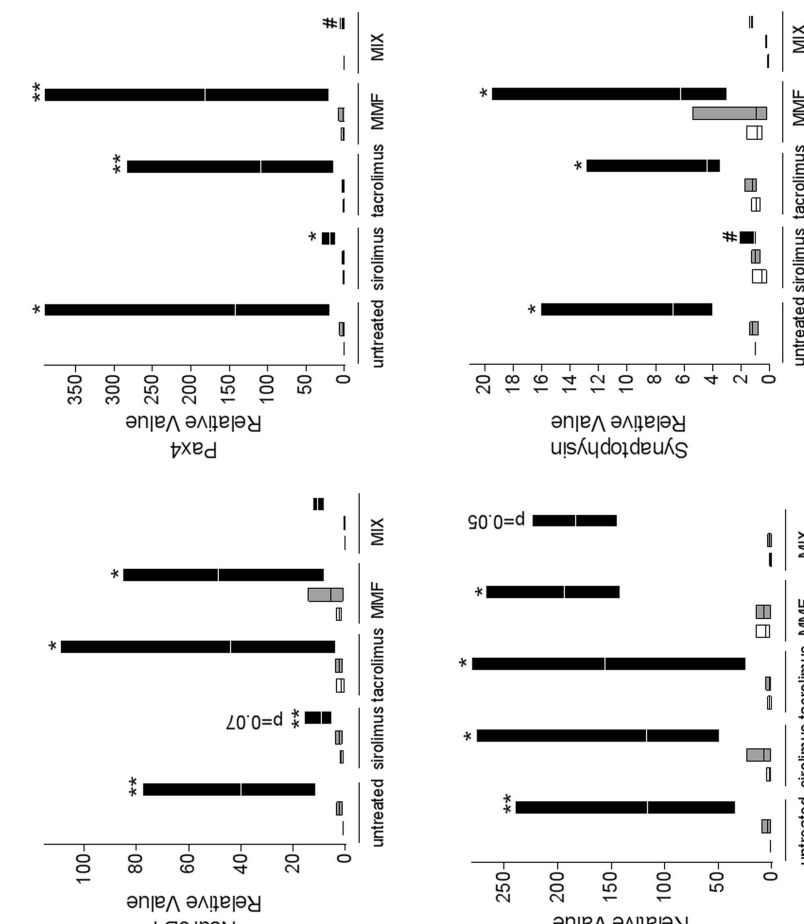

$\leftarrow$

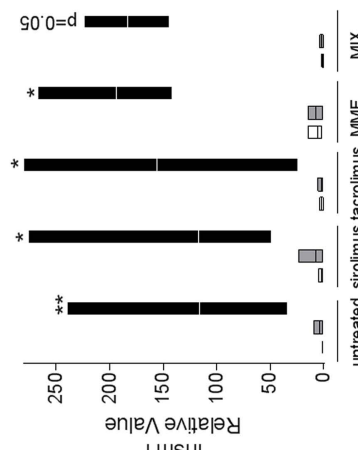

เusu|

$\square \square \square$

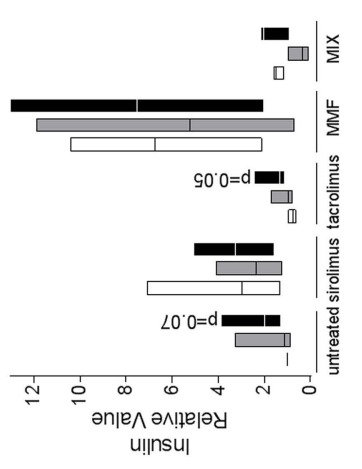


were immunopositive for synaptophysin and insulin augmented to $4 \%$ and $1 \%$, respectively (Fig. 5B). Tacrolimus and MMF had no significant effect on this reprogramming capacity of adult human pancreatic duct cells, while sirolimus alone or in combination therapy inhibited expression of NeuroD1 (at mRNA level), Pax4 (at mRNA level), and synaptophysin (at both mRNA and protein level). Of note, MMF seemed to promote AdNgn3-GFP-driven $\beta$-cell differentiation more effectively than AdNgn3-GFP in the other treatment scenarios.

\section{DISCUSSION}

We and others have demonstrated that the implant composition, with $\beta$-cell number and viability (23) and the proportion of other endocrine and nonendocrine cells (43) are influential variables correlating with transplant function over time. The value of pancreatic duct cells in islet preparations for transplantation remains provocative. Yet, there is indirect evidence that the high percent pancreatic duct cells in grafts can influence the transplantation outcome $(20,22,24,38,43,47)$, which alludes to a possible role of these cells in $\beta$-cell renewal. Their presence may indeed hold a positive contribution if they contain $\beta$-cell precursors (6) or if they secrete functionally relevant concentrations of angiogenic factors $(19,32,47)$ or hematopoietic growth factors (26). On the other hand, pancreatic duct cells have a strong proinflammatory connotation, both because they produce nitric oxide and inflammatory cytokines $(1,19,33,36)$, which are directly cytotoxic to $\beta$-cells, and because they produce tissue factor, which exerts a potent factor VII-dependent procoagulant activity (4). As these cells are currently a common "contaminant" of human islet preparations and are cotransplanted with them, we studied how classical immunosuppressants affect their inflammatory, angiogenic, proliferative, and reprogramming potential.

In our study, sirolimus suppressed the expression of TNF- $\alpha$. Mita et al. also demonstrated that highdose sirolimus supplementation in culture $(30 \mathrm{ng} / \mathrm{ml})$ decreased TNF- $\alpha$ production especially in impure human islet preparations (HIP) and pure pancreatic duct cells but not in pure HIP. They found that sirolimus reduced macrophage numbers in impure HIP, which might explain the reduction in cytokine release (31). Although sirolimus has been shown to negatively impact islet revascularization in rodent models of T1D possibly by inhibiting the proliferation and differentiation of endothelial cells and by inhibiting VEGF secretion (9), we found that sirolimus promoted the expression of the proangiogenic chemokine IL-8 by human pancreatic duct cells shortly after transplantation and had no damaging effect on VEGF expression and the angiogenic ability of duct cells in vivo. This research area remains very heterogeneous, using a variety of cell types, drug concentrations, and treatment periods. Indeed, at supratherapeutic concentrations sirolimus $(\sim 100 \mathrm{ng} / \mathrm{ml})$ has been shown to exert deleterious effects on the viability of rat and human islets (3). Moreover, Ko et al. reported that high-dose sirolimus reduced expression of VEGF and VEGF receptor mRNA and protein in a kidney model of chronic allograft dysfunction (27). Therefore, we cannot exclude the inhibiting effect of sirolimus on VEGF expression and secretion if administered at higher doses and for a longer time period. We also found that tacrolimus did not affect IL-8 and VEGF expression and angiogenic capacity of duct cells in vivo, but suppressed expression of all inflammatory cytokines tested, especially at 6 days after human pancreatic duct cell implantation under the kidney capsule. Inhibition of cytokine production by T-lymphocytes is considered one of the major clinical effects of tacrolimus (45), and most probably, also in pancreatic duct cells, calcineurin inhibition will lay at the basis of the reduction of cytokine expression. Finally, MMF suppressed the expression of IL-1 $\beta$ and TNF- $\alpha$ by human pancreatic duct cells quite dramatically and did not significantly affect the angiogenic factors tested. Of note, different implantation organs (e.g., kidney subcapsular vs. liver intraportal) may likely provide different environments for the grafted human pancreatic duct cells, with a variable capacity of the cells for inflammation, survival, and revascularization. Moreover, we acknowledge that dose-dependent effects of immunosuppressive drugs on the different aspects of the human pancreatic duct cells cannot be excluded. Nevertheless, we put forward that the reduction in cytokine expression together with the absence of an inhibitory effect on the angiogenic potential of pancreatic

\section{FACING PAGE}

Figure 5. Effects of immunosuppressants on pancreatic duct cell reprogramming. Human pancreatic duct cells transduced with or without AdNgn3-GFP were cultured in the absence or presence of immunosuppressants. (A) NeuroD1, Pax4, Insm1, synaptophysin, and insulin mRNA expression measured by RT-qPCR and normalized to RPL27. Data are displayed in floating bar plots with minmax and median values of three to four separate experiments. (B) Quantitation of synaptophysin ${ }^{+}$or of insulin ${ }^{+}$cells (percentage of total cells). Synaptophysin (red), insulin (magenta), and GFP (green) immunofluorescent staining (magnification 20x; scale bar: $100 \mu \mathrm{m}$, inset magnification 60x; scale bar: $10 \mu \mathrm{m}$ ). Nuclei are stained blue (DAPI). Data are displayed in floating bar plots with min-max and median values from four to eight independent experiments. Statistical significance was determined by nonparametric Kruskal-Wallis test followed by the Dunn's multiple testing. Multiplicity-adjusted $p$ values were used as $* p<0.05, * * p<0.01$ for AdNgn3-GFP compared to no Ad in each corresponding condition; $\# p<0.05$ for treated AdNgn3-GFP compared to untreated AdNgn3-GFP. Nd, not detectable. 
duct cells observed after kidney subcapsular implantation might contribute to the spectacular improvements in the success rate of 1-year insulin independence of sirolimus/ tacrolimus-based steroid-free immunosuppressive regimen used in the Edmonton protocol (43).

Nowadays, there is growing consciousness that the pancreatic duct cells have the potential to differentiate into islet cells. Ectopic overexpression of $\mathrm{Ngn} 3$ activated the expression of endocrine cell- and $\beta$-cell-specific markers in human pancreatic duct cells $(17,28)$, indicating that duct cells can be reprogrammed to a (neuro)endocrine phenotype. Transplantation models confirmed the differentiation capacity of human pancreatic duct cells from young donors less than 10 years, as evidenced by a low portion of insulin ${ }^{+}$cells that were also $\mathrm{CK} 19^{+}$and in close connection with duct epithelia (5). We put forward that current immunosuppressive regimens required to interfere with both allo- and autoimmunity in islet transplantation may not only be overwhelming for the proliferative and $\beta$-cell differentiating capacity of adult $\beta$-cells (34) but also of pancreatic duct cells. Although we did not observe direct toxic effects on pancreatic duct cells by any of immunosuppressants or their combination studied, we found a clear inhibition of duct cell proliferation by MMF and sirolimus; the latter also affecting duct-to-(neuro) endocrine reprogramming, as defined by Pax4, NeuroD1, and synaptophysin expression. Previously, MMF, alone or in combination with low-dose sirolimus or tacrolimus, was found to inhibit proliferation of islet precursor cells (12). In addition to inhibition of DNA synthesis and cell proliferation, the active compound of MMF (mycophenolic acid) has been shown to induce precocious secondary islets, which are formed solely by differentiation from ductal progenitors in zebrafish larvae, through inhibition of inosine 5-monophosphate dehydrogenase (IMPDH) (40). IMPDH is a key enzyme in de novo synthesis of guanosine-5-triphosphate (GTP). We speculate that also in our human adult pancreatic duct cell cultures MMF possibly affected duct-to-(neuro)endocrine reprogramming through inhibition of IMPDH and suppression of cellular GTP levels. For the case of sirolimus, a few groups reported inhibition of proliferation of both pancreatic islet $\beta$ - and duct cells, which might lead to loss of long-term islet function by reducing $\beta$-cell renewal from duct cells $(7,49)$. Sirolimus acts by forming a complex with FK-506 binding protein 12 that binds to the mammalian target of rapamycin (mTOR), thereby inhibiting its activity and leading to a block in $\mathrm{G}_{1}$ to $\mathrm{S}$ transition of the cell cycle (11). mTORC1 and mTORC2 are two separate complexes sharing mTOR as a catalytic subunit. mTORC1 is highly sensitive to sirolimus, whereas, overall, mTORC2 is sirolimus insensitive. mTORC1 plays a key role in the regulation of $\beta$-cell size and replication. These effects are likely mediated by the mTOR-p70 S6 protein kinase-1 complex. On the other hand, the long-term detrimental effects of sirolimus in islet $\beta$-cells are closely related to the dissociation and inactivation of mTORC2 assembly and the inhibition of protein kinase B (2). Of note, Gao et al. demonstrated that low-dose sirolimus $(10 \mathrm{ng} / \mathrm{ml})$ had a marginal stimulatory effect on basal pancreatic duct cell proliferation (12). In our hands, high-dose sirolimus (25 $\mathrm{ng} / \mathrm{ml}$ ) not only inhibited duct cell proliferation but also duct-to-(neuro)endocrine cell reprogramming. This implies that by administering sirolimus to islet recipients, long-term graft function might be inhibited by decreasing $\beta$-cell neogenesis. In contrast, sirolimus has also been shown to improve glucose-stimulated insulin release in impure HIP in culture (32). The authors suggested that sirolimus directly reduced the number of macrophages in HIP, leading to the reduction of cytokines/chemokines release. For tacrolimus, we did not find any significant inhibitory effect on duct cell proliferation nor on reprogramming. Also here, conflicting data exist demonstrating that tacrolimus can affect $\beta$-cell differentiation in vitro (12). Moreover, negative effects on insulin exocytosis and $\beta$-cell differentiation in islet implants have been reported by tacrolimus therapy $(12,21)$.

In conclusion, our current data indicate that conventional immunosuppressant agents used in clinical islet transplantation counteract the proinflammatory, proliferative, and reprogramming properties of human adult pancreatic duct cells. Among these immunosuppressants, tacrolimus was the least aggressive in affecting the angiogenic, proliferative, and Ngn3-mediated neuro(endocrine) reprogramming potential of human pancreatic duct cells, while it was most powerful in inhibiting their inflammatory cytokines. These data should be considered when making a choice in maintenance immunosuppressants, in particular in the context of clinical islet transplantation, favoring tacrolimus.

ACKNOWLEDGMENTS: We thank Eefje Verdrengh, Jos Laureys, and Tom Haex for their excellent technical assistance, and the Eurotransplant Foundation as well as the Beta Cell Bank for providing human pancreatic duct cell preparations. We also thank Yu Jin and Annouschka Laenen for statistical advice. This work was supported by grants from the KU LEUVEN (GOA 2009/10), the Belgian government (Interuniversity Attraction Poles, program P6/40 of the Belgian Federal Science Policy Office), the European Community's Health Seventh Framework Programme (FP7/2010-2014 under grant agreement 241883 with acronym BETACELLTHERAPY), and from the Juvenile Diabetes Research Foundation (center grant 4-2005-1327). L.D. is supported through an IRO fellowship of the KU LEUVEN. Y.H. is a researcher from Vrije Universiteit Brussel, Diabetes Research Center; C.M. is a clinical researcher of the FWO Vlaanderen. C.G. is supported by the European Community's Health Seventh Framework Programme (FP7/2009-2014 under grant agreement 241447 with acronym NAIMIT) and the KU LEUVEN. H.H. is professor of Vrije Universiteit Brussels, Diabetes Research Center. D.P. is director of Vrije Universiteit Brussels, Diabetes Research Center. Conceived and designed 
the experiments: L.D., Y.H., D.P., H.H., C.G., and C.M. Performed the experiments: L.D., Y.H., and C.G. Analyzed the data: L.D., Y.H., and C.G. Contributed reagents/materials/ analysis tools: Y.H. and D.P. Wrote the article: L.D., Y.H., D.P., H.H., C.G., and C.M.

\section{REFERENCES}

1. Barbe-Tuana, F. M.; Klein, D.; Ichii, H.; Berman, D. M.; Coffey, L.; Kenyon, N. S.; Ricordi, C.; Pastori, R. L. CD40CD40 ligand interaction activates proinflammatory pathways in pancreatic islets. Diabetes 55(9):2437-2445; 2006.

2. Barlow, A. D.; Xie, J.; Moore, C. E.; Campbell, S. C.; Shaw, J. A.; Nicholson, M. L.; Herbert, T. P. Rapamycin toxicity in MIN6 cells and rat and human islets is mediated by the inhibition of mTOR complex 2 (mTORC2). Diabetologia 55(5):1355-1365; 2012.

3. Bell, E.; Cao, X.; Moibi, J. A.; Greene, S. R.; Young, R.; Trucco, M.; Gao, Z.; Matschinsky, F. M.; Deng, S.; Markman, J. F.; Naji, A.; Wolf, B. A. Rapamycin has a deleterious effect on MIN-6 cells and rat and human islets. Diabetes 52(11):2731-2739; 2003.

4. Beuneu, C.; Vosters, O.; Movahedi, B.; Remmelink, M.; Salmon, I.; Pipeleers, D.; Pradier, O.; Goldman, M.; Verhasselt, V. Human pancreatic duct cells exert tissue factor-dependent procoagulant activity: Relevance to islet transplantation. Diabetes 53(6):1407-1411; 2004.

5. Bogdani, M.; Lefebvre, V.; Buelens, N.; Bock, T.; PipeleersMarichal, M.; In't Veld, P.; Pipeleers, D. Formation of insulinpositive cells in implants of human pancreatic duct cell preparations from young donors. Diabetologia 46(6):830 838; 2003.

6. Bonner-Weir, S.; Toschi, E.; Inada, A.; Reitz, P.; Fonseca, S. Y.; Aye, T.; Sharma, A. The pancreatic ductal epithelium serves as a potential pool of progenitor cells. Pediatr. Diabetes 5(Suppl 2):16-22; 2004.

7. Bussiere, C. T.; Lakey, J. R.; Shapiro, A. M.; Korbutt, G. S. The impact of the mTOR inhibitor sirolimus on the proliferation and function of pancreatic islets and ductal cells. Diabetologia 49(10):2341-2349; 2006.

8. Cantaluppi, V.; Biancone, L.; Romanazzi, G. M.; Figliolini, F.; Beltramo, S.; Ninniri, M. S.; Galimi, F.; Romagnoli, R.; Franchello, A.; Salizzoni, M.; Perin, P. C.; Ricordi, C.; Segoloni, G. P.; Camussi, G. Antiangiogenic and immunomodulatory effects of rapamycin on islet endothelium: Relevance for islet transplantation. Am. J. Transplant. 6(11):2601-2611; 2006

9. Cross, S. E.; Richards, S. K.; Clark, A.; Benest, A. V.; Bates, D. O.; Mathieson, P. W.; Johnson, P. R.; Harper, S. J.; Smith, R. M. Vascular endothelial growth factor as a survival factor for human islets: Effect of immunosuppressive drugs. Diabetologia 50(7):1423-1432; 2007.

10. Delaney, C. A.; Pavlovic, D.; Hoorens, A.; Pipeleers, D. G.; Eizirik, D. L. Cytokines induce deoxyribonucleic acid strand breaks and apoptosis in human pancreatic islet cells. Endocrinology 138(6):2610-2614; 1997.

11. Dumont, F. J.; Su, Q. Mechanism of action of the immunosuppressant rapamycin. Life Sci. 58(5):373-395; 1996.

12. Gao, R.; Ustinov, J.; Korsgren, O.; Otonkoski, T. Effects of immunosuppressive drugs on in vitro neogenesis of human islets: Mycophenolate mofetil inhibits the proliferation of ductal cells. Am. J. Transplant. 7(4):1021-1026; 2007.

13. Giulietti, A.; van Etten, E.; Overbergh, L.; Stoffels, K.; Bouillon, R.; Mathieu, C. Monocytes from type 2 diabetic patients have a pro-inflammatory profile. 1,25Dihydroxyvitamin D(3) works as anti-inflammatory. Diabetes Res. Clin. Pract. 77(1):47-57; 2007.

14. He, T. C.; Zhou, S.; da Costa, L. T.; Yu, J.; Kinzler, K. W.; Vogelstein, B. A simplified system for generating recombinant adenoviruses. Proc. Natl. Acad. Sci. USA 95(5):25092514; 1998.

15. Heimberg, H.; Bouwens, L.; Heremans, Y.; Van De Casteele, M.; Lefebvre, V.; Pipeleers, D. Adult human pancreatic duct and islet cells exhibit similarities in expression and differences in phosphorylation and complex formation of the homeodomain protein Ipf-1. Diabetes 49(4):571-579; 2000.

16. Heimberg, H.; Heremans, Y.; Jobin, C.; Leemans, R.; Cardozo, A. K.; Darville, M.; Eizirik, D. L. Inhibition of cytokine-induced NF-kappaB activation by adenovirusmediated expression of a NF-kappaB super-repressor prevents beta-cell apoptosis. Diabetes 50(10):2219-2224; 2001.

17. Heremans, Y.; Van De Casteele, M.; in't Veld, P.; Gradwohl, G.; Serup, P.; Madsen, O.; Pipeleers, D.; Heimberg, H. Recapitulation of embryonic neuroendocrine differentiation in adult human pancreatic duct cells expressing neurogenin 3. J. Cell. Biol. 159(2):303-312; 2002.

18. Huurman, V. A.; Hilbrands, R.; Pinkse, G. G.; Gillard, P.; Duinkerken, G.; van de Linde, P.; van der Meer-Prins, P. M.; Versteeg-van der Voort Maarschalk, M. F.; Verbeeck, K.; Alizadeh, B. Z.; Mathieu, C.; Gorus, F. K.; Roelen, D. L.; Claas, F. H.; Keymeulen, B.; Pipeleers, D. G.; Roep, B. O. Cellular islet autoimmunity associates with clinical outcome of islet cell transplantation. PLoS One 3(6):e2435; 2008.

19. Ichii, H.; Miki, A.; Yamamoto, T.; Molano, R. D.; Barker, S.; Mita, A.; Rodriguez-Diaz, R.; Klein, D.; Pastori, R.; Alejandro, R.; Inverardi, L.; Pileggi, A.; Ricordi, C. Characterization of pancreatic ductal cells in human islet preparations. Lab. Invest. 88(11):1167-1177; 2008.

20. Jacobs-Tulleneers-Thevissen, D.; Bartholomeus, K.; Suenens, K.; Vermeulen, I.; Ling, Z.; Hellemans, K. H.; In't Veld, P.; Pipeleers-Marichal, M.; Pipeleers, D. Human islet cell implants in a nude rat model of diabetes survive better in omentum than in liver with a positive influence of beta cell number and purity. Diabetologia 53(8):1690-1699; 2010.

21. Johnson, J. D.; Ao, Z.; Ao, P.; Li, H.; Dai, L. J.; He, Z.; Tee, M.; Potter, K. J.; Klimek, A. M.; Meloche, R. M.; Thompson, D. M.; Verchere, C. B.; Warnock, G. L. Different effects of FK506, rapamycin, and mycophenolate mofetil on glucose-stimulated insulin release and apoptosis in human islets. Cell Transplant. 18(8):833-845; 2009.

22. Keymeulen, B.; Anselmo, J.; Pipeleers, D. Length of metabolic normalization after rat islet cell transplantation depends on endocrine cell composition of graft and on donor age. Diabetologia 40(10):1152-1158; 1997.

23. Keymeulen, B.; Gillard, P.; Mathieu, C.; Movahedi, B.; Maleux, G.; Delvaux, G.; Ysebaert, D.; Roep, B.; Vandemeulebroucke, E.; Marichal, M.; In'tVeld, P.; Bogdani, M.; Hendrieckx, C.; Gorus, F.; Ling, Z.; van Rood, J.; Pipeleers, D. Correlation between beta cell mass and glycemic control in type 1 diabetic recipients of islet cell graft. Proc. Natl. Acad. Sci. USA 103(46):17444-17449; 2006.

24. Keymeulen, B.; Korbutt, G.; De Paepe, M.; Gorus, F.; Kloppel, G.; Pipeleers, D. G. Long-term metabolic control by rat islet grafts depends on the composition of the implant. Diabetes 45(12):1814-1821; 1996. 
25. Keymeulen, B.; Ling, Z.; Gorus, F. K.; Delvaux, G.; Bouwens, L.; Grupping, A.; Hendrieckx, C.; PipeleersMarichal, M.; Van Schravendijk, C.; Salmela, K.; Pipeleers, D. G. Implantation of standardized beta-cell grafts in a liver segment of IDDM patients: Graft and recipients characteristics in two cases of insulin-independence under maintenance immunosuppression for prior kidney graft. Diabetologia 41(4):452-459; 1998.

26. Klein, D.; Timoneri, F.; Ichii, H.; Ricordi, C.; Pastori, R. L. CD40 activation in human pancreatic islets and ductal cells. Diabetologia 51(10): 1853-1861; 2008.

27. Ko, H. T.; Yin, J. L.; Wyburn, K.; Wu, H.; Eris, J. M.; Hambly, B. D.; Chadban, S. J. Sirolimus reduces vasculopathy but exacerbates proteinuria in association with inhibition of VEGF and VEGFR in a rat kidney model of chronic allograft dysfunction. Nephrol. Dial. Transplant. 28(2):327-336; 2013.

28. Lee, J.; Sugiyama, T.; Liu, Y.; Wang, J.; Gu, X.; Lei, J.; Markmann, J. F.; Miyazaki, S.; Miyazaki, J. I.; Szot, G. L.; Bottino, R.; Kim, S. K. Expansion and conversion of human pancreatic ductal cells into insulin-secreting endocrine cells. Elife 2:e00940; 2013.

29. Li, F.; Li, Q. Effects of different dose of FK506 on endocrine function of pancreatic islets and damage of beta cells of pancreatic islets in a Wistar rat model. Immunopharmacol. Immunotoxicol. 32(2):333-338; 2010.

30. Maes, B. D.; Kuypers, D.; Messiaen, T.; Evenepoel, P.; Mathieu, C.; Coosemans, W.; Pirenne, J.; Vanrenterghem, Y. F. Posttransplantation diabetes mellitus in FK-506treated renal transplant recipients: Analysis of incidence and risk factors. Transplantation 72(10):1655-1661; 2001.

31. Mita, A.; Ricordi, C.; Miki, A.; Barker, S.; Haertter, R.; Hashikura, Y.; Miyagawa, S.; Burke, 3rd., G. W.; Inverardi, L.; Ichii, H. Anti-proinflammatory effects of sirolimus on human islet preparations. Transplantation 86(1):46-53; 2008.

32. Movahedi, B.; Gysemans, C.; Jacobs-Tulleneers-Thevissen, D.; Mathieu, C.; Pipeleers, D. Pancreatic duct cells in human islet cell preparations are a source of angiogenic cytokines interleukin-8 and vascular endothelial growth factor. Diabetes 57(8):2128-2136; 2008.

33. Movahedi, B.; Van de Casteele, M.; Caluwe, N.; Stange, G.; Breckpot, K.; Thielemans, K.; Vreugdenhil, G.; Mathieu, C.; Pipeleers, D. Human pancreatic duct cells can produce tumour necrosis factor-alpha that damages neighbouring beta cells and activates dendritic cells. Diabetologia 47(6):998-1008; 2004.

34. Nir, T.; Melton, D. A.; Dor, Y. Recovery from diabetes in mice by beta cell regeneration. J. Clin. Invest. 117(9):25532561; 2007.

35. Overbergh, L.; Giulietti, A.; Valckx, D.; Decallonne, R.; Bouillon, R.; Mathieu, C. The use of real-time reverse transcriptase PCR for the quantification of cytokine gene expression. J. Biomol. Tech. 14(1):33-43; 2003.

36. Pavlovic, D.; Chen, M. C.; Bouwens, L.; Eizirik, D. L.; Pipeleers, D. Contribution of ductal cells to cytokine responses by human pancreatic islets. Diabetes 48(1):29-33; 1999.

37. Pfaffl, M. W. A new mathematical model for relative quantification in real-time RT-PCR. Nucleic Acids Res. 29(9):e45; 2001.
38. Pipeleers, D. G.; Pipeleers-Marichal, M.; Vanbrabandt, B.; Duys, S. Transplantation of purified islet cells in diabetic rats. II. Immunogenicity of allografted islet beta-cells. Diabetes 40(7):920-930; 1991.

39. Rescan, C.; Le Bras, S.; Lefebvre, V. H.; Frandsen, U.; Klein, T.; Foschi, M.; Pipeleers, D. G.; Scharfmann, R.; Madsen, O. D.; Heimberg, H. EGF-induced proliferation of adult human pancreatic duct cells is mediated by the MEK/ ERK cascade. Lab. Invest .85(1):65-74; 2005.

40. Rovira, M.; Huang, W.; Yusuff, S.; Shim, J. S.; Ferrante, A. A.; Liu, J. O.; Parsons, M. J. Chemical screen identifies FDA-approved drugs and target pathways that induce precocious pancreatic endocrine differentiation. Proc. Natl. Acad. Sci. USA 108(48):19264-19269; 2011.

41. Shapiro, A. M.; Lakey, J. R.; Ryan, E. A.; Korbutt, G. S.; Toth, E.; Warnock, G. L.; Kneteman, N. M.; Rajotte, R. V. Islet transplantation in seven patients with type 1 diabetes mellitus using a glucocorticoid-free immunosuppressive regimen. N. Engl. J. Med. 343(4):230-238; 2000.

42. Shapiro, A. M.; Ricordi, C.; Hering, B. J.; Auchincloss, H.; Lindblad, R.; Robertson, R. P.; Secchi, A.; Brendel, M. D.; Berney, T.; Brennan, D. C.; Cagliero, E.; Alejandro, R.; Ryan, E. A.; DiMercurio, B.; Morel, P.; Polonsky, K. S.; Reems, J. A.; Bretzel, R. G.; Bertuzzi, F.; Froud, T.; Kandaswamy, R.; Sutherland, D. E.; Eisenbarth, G.; Segal, M.; Preiksaitis, J.; Korbutt, G. S.; Barton, F. B.; Viviano, L.; Seyfert-Margolis, V.; Bluestone, J.; Lakey, J. R. International trial of the Edmonton protocol for islet transplantation. N. Engl. J. Med. 355(13):1318-1330; 2006.

43. Street, C. N.; Lakey, J. R.; Shapiro, A. M.; Imes, S.; Rajotte, R. V.; Ryan, E. A.; Lyon, J. G.; Kin, T.; Avila, J.; Tsujimura, T.; Korbutt, G. S. Islet graft assessment in the Edmonton Protocol: Implications for predicting long-term clinical outcome. Diabetes 53(12):3107-3114; 2004.

44. Swales, N.; Martens, G. A.; Bonne, S.; Heremans, Y.; Borup, R.; Van de Casteele, M.; Ling, Z.; Pipeleers, D.; Ravassard, P.; Nielsen, F.; Ferrer, J.; Heimberg, H. Plasticity of adult human pancreatic duct cells by neurogenin3-mediated reprogramming. PLoS One 7(5):e37055; 2012.

45. Thomson, A. W.; Bonham, C. A.; Zeevi, A. Mode of action of tacrolimus (FK506): Molecular and cellular mechanisms. Ther. Drug Monit. 17(6):584-591; 1995.

46. Van Belle, T.; von Herrath, M. Immunosuppression in islet transplantation. J. Clin. Invest. 118(5):1625-1628; 2008

47. Xiao, X.; Prasadan, K.; Guo, P.; El-Gohary, Y.; Fischbach, S.; Wiersch, J.; Gaffar, I.; Shiota, C.; Gittes, G. K. Pancreatic duct cells as a source of VEGF in mice. Diabetologia 57(5):991-1000; 2014.

48. Yatoh, S.; Dodge, R.; Akashi, T.; Omer, A.; Sharma, A.; Weir, G. C.; Bonner-Weir, S. Differentiation of affinitypurified human pancreatic duct cells to beta-cells. Diabetes 56(7):1802-1809; 2007.

49. Zahr, E.; Molano, R. D.; Pileggi, A.; Ichii, H.; Jose, S. S.; Bocca, N.; An, W.; Gonzalez-Quintana, J.; Fraker, C.; Ricordi, C.; Inverardi, L. Rapamycin impairs in vivo proliferation of islet beta-cells. Transplantation 84(12):1576$1583 ; 2007$. 